\title{
KONSEP HUKUM ZAKAT SEBAGAI INSTRUMEN DALAM MENINGKATKAN PEREKONOMIAN UMMAT
}

\author{
Naimah \\ Fakultas Syari'ah dan Ekonomi Islam IAIN Antasari, Jl. Jendral Ahmad Yani Km 4,5 Banjarmasin.
}

\begin{abstract}
Zakat is charity of worship and included in the five pillars of Islam, because zakat is the foundation of Islam, in addition to an absolute obligation for a Muslim. It is also fully aware that the charity is a key instrument in growing the economy and improving the distribution tool. Then during the practice of Prophet Muhammad Saw in the compulsory zakat in times of Apostle in Medina, where nishab is set up, and stats is responsible in managing. This study explores how the concept of charity law as an instrument to improve the economy ummah, how positive law in Indonesia, which was formed to be able to institutionalize zakat order to function optimally, huge potential utilization of zakat can be achieved. The findings showed that generally, the presence of act No. 23 of 2011 on the management of zakat was instrumental in the development of the organization or institution of zakat in Indonesia, because the act provides legal certainty for the operational organization of zakat, and increased public awareness in regular charity through zakat institution or organization zakat. In addition, this act provides the foundation for the implementation of the concept of zakat productive.This law can be important instrument to achieve the goal of zakat as the remover of poverty, reduce unemployment and improve the ummah's economy.
\end{abstract}

Abstrak: Zakat adalah ibadah maliyah dan termasuk dalam rukun islam yang lima, karena itu zakat merupakan pondasi agama islam, selain merupakan kewajiban mutlak bagi seorang muslim, disadari secara penuh juga bahwa zakat merupakan instrumen kunci dalam menumbuhkan dan meningkatkan perekonomian ummat, dengan peran besarnya yang mampu menjadi alat distribusi kesejahteraan ummat. Dalam sejarahnya praktek zakat sudah di lakukan sebelum zaman Rasulullah Muhammad SAW, lalu pada masa Rasul Muhammad SAW praktek pengelolaan zakat mendapat bentuk yang lebih baik khususnya ketika zakat yang di wajibkan pada masa-masa Rasul di madinah, dimana nishab dan besarnya sudah ditentukan, orang-orang yang mengumpulkan dan membagikannya sudah diatur, dan negara bertanggung jawab mengelolakannya. Kajian ini mengupas tentang bagaimana konsep hukum zakat sebagai instrumen dalam meningkatkan perekonomian ummat, bagaimana hukum positif di Indonesia yang dibentuk untuk mampu melembagakan zakat supaya dapat berfungsi maksimal, potensi-potensi besar pendayagunaan zakat dapat diraih. Hasil kajian menunjukkan bahwa Secara umum, kehadiran Undang-Undang Nomor 23 tahun 2011 Tentang pengelolaan zakat sangat berperan dalam perkembangan organisasi pengelola zakat atau lembaga zakat di Indonesia, karena Undang-undang ini memberikan kepastian hukum bagi operasional organisasi pengelola zakat (OPZ), serta Meningkatnya kesadaran masyarakat dalam menunaikan zakat melalui lembaga zakat atau organisasi pengelola zakat (OPZ). Selain itu Undangundang ini juga memberikan landasan bagi terlaksananya konsep zakat produktif. Undang-Undang ini dapat menjadi instrumen penting untuk mencapai cita-cita zakat sebagai penghapus kemiskinan, mengurangi pengangguran dan serta meningkatkan perekenomian ummat.

Kata Kunci : Zakat, konsep bukum, perekonomian Ummat.

\section{Pendahuluan}

Zakat adalah ibadah yang memiliki dua dimensi, yaitu vertikal dan horizontal. Zakat merupakan ibadah sebagai bentuk ketaatan kepada Allah (bablu minallah) dan sebagai kewajiban kepada sesama manusia (hablu minannaas). Zakat juga sering disebut sebagai ibadah kesungguhan dalam harta (maaliyah ijtihadiyah). Tingkat pentingnya zakat terlihat dari banyaknya ayat yang 
menyandingkan perintah zakat dengan perintah shalat. ${ }^{1}$

Zakat merupakan salah satu ciri dari system ekonomi Islam, karena zakat merupakan salah satu implementasi asas keadilan dalam sistem ekonomi Islam. Dengan zakat, Allah menghendaki kebaikan kehidupan manusia agar hidup tolong menolong, gotong royong dan selalu menjalin persaudaraan. Adanya perbedaan harta, kekayaan, dan status sosial dalam kehidupan adalah sunatullah yang tidak mungkin dihilangkan sama sekali. Bahkan adanya perbedaan status sosial itulah manusia saling membutuhkan antara satu dengan lainnya. ${ }^{2}$

Zakat adalah ibadah maaliyah ijtimaiyah yang memiliki posisi yang sangat penting, strategis, dan menentukan, baik dilihat dari sisi ajaran Islam maupun dari sisi pembangunan kesejahteraan umat. Sebagai ibadah pokok, zakat termasuk salah satu rukun (rukun ketiga) dari rukun Islam yang lima, sebagaimana diungkapkan dalam berbagai hadits Nabi. Keberadaan zakat dianggap sebagai ma'luumun minad-diin bidharuurah atau diketahui secra otomatis adanya dan merupakan bagian mutlak dari keislaman seseorang. ${ }^{3}$

Dengan zakat, Allah SWT menyucikan harta, dan menghendaki kebaikan untuk kehidupan manusia melalui hukum Allah, agar kirang saling tolong menolong dan selalu menjalin persaudaraan. Adanya perbedaan harta kekayaan dan status social dalam kehidupan adalah sunatullah yang tidak mungkin dihilangkan sama sekali. Bahkan adanya perbedaan status social itu manusia membutuhkan antara satu dengan lainnya. Dan zakat adalah salah satu instrument yang paling efektif untuk menyatukan umat manusia dalam naungan kecintaan dan kedamaian hidup didunia untuk menggapai kebaikan di akhirat. ${ }^{4}$

\section{Pengertian Zakat}

Zakat ditinjau dari segi bahasa (lughatan) mempunyai beberapa arti, yaitu keberkahan (albarkatu), pertumbuhan dan perkembangan (alnama), kesucian (ath-thabaratu). Sedangkan arti

\footnotetext{
${ }^{1}$ H. Hikmat Kurnia dan H.A. Hidayat, 2008, Panduan Pintar Zakat, Jakarta, Qultum Media, hlm. 8

2 Ibid, hlm. 2.

3 Didin Hafidhuddin dan Rahmat Pramulya, Kaya Karena berzakat, 2008, Jakarta, Raih Asa Sukses, hlm.7

4 H. Hikmat Kurnia dan H.A. Hidayat, Op. cit, hlm. 1
}

zakat menurut istilah (syar'iyab), yaitu merupakan bagian dari harta dengan persyaratan tertentu , yang Allah SWT mewajibkan kepada pemiliknya untuk diserahkan kepada yang berhak menerimannya, dengan persyaratan tertentu pula. ${ }^{5}$

\section{Dasar Hukum Zakat}

Di dalam Al-Qur'an banyak terdapat ayat yang secara tegas memerintahkan pelaksanaan zakat. Perintah Allah SWT tentang zakat tersebut seringkali beriringan dengan perintah salat. Perintah zakat dalam Al-Qur'an ditemukan sebanyak 32 kali, 26 kali diantaranya disebutkan bersamaan dengan kata salat. Hal ini mengisyaratkan bahwa kewajiban mengeluarkan zakat seperti halnya kewajiban mendirikan salat. ${ }^{6}$

Zakat diwajibkan berdasarkan Al-Qur'an dan Hadist Nabi Muhammad. Dalil-dalil yang terdapat dalam Al-Qur'an banyak menggunakan bentuk amar (perintah) atau intruksi sebagaimana yang terdapat dalam surat At-Taubah ayat 103.

Firman Allah dalam At-Taubah ayat 103:7

Artinya: Ambillah zakat dari harta mereka, guna membersihkan dan mensucikan mereka. Dan berdoalah untuk mereka. Sesungguhnya doamu itu (menumbuhkan) ketentraman jiwa bagi mereka. Allah Maha Mendengar, Maha Mengetahui.

\section{Sumber- Sumber Zakat}

Adapun Sumber- sumber zakat, yaitu: ${ }^{8}$

1. Hewan Ternak. Dalam berbagai hadist dikemukakan bahwa hewan ternak yang wajib dikeluarkan zakatnya setelah memenehi persyaratan tertentu ada tiga jenis, yaitu unta, sapi, dan domba atau kambing. Dan para ulama juga telah bersepakat kewajiban zakat pada tiga jenis, yaitu unta, sapi, dan domba. Sedangkan diluar ketiga jenis tersebut, para ulama berbeda pendapat. Abu Hanifah berpendapat bahwa pada binatang kuda dikenakan kewajiban zakat,

5 H. Ismail Nawawi, Zakat Dalam Perspektif Fiqh,Sosial \& Ekonomi, 2010, Surabaya, Putra Media Nusantara, hlm. 1

6 Iqbal M. Ambara, 2009, Problematika Zakat Dan Pajak. Di Indonesia, tt, Sketsa, hlm. 23.

7 Departemen Agama, 2007, Lajnah Pentashib Mushaf AlQur;an, Solo, PT. Tiga Serangkai Pustaka Mandiri, hlm. 203.

8 Didin Hafidhuddin, 2008, Zakat Dalam Perekonomian Modern, Jakarta, Gema Insani, hlm. 29. 
sedangkan Imam Malik dan Imam Safi'I tidak mewajibkannya, kecuali bila kuda itu diperjualbelikan. Apabila diperhatikan dari dalildalil dalam Al-Qur'an dan hadist serta pendapat para ulama, dapat disimpulkan bahwa hewan ternak selain unta, sapi, dan domba, seperti unggas, tidaklah termasuk pada kategori zakat hewan ternak, melainkan zakat perdagangan.

2. Emas dan Perak. Kewajiban mengeluarkan zakat emas dan perak setelah memenuhi persyaratan tertentu dinyatakan dalam surat AtTaubah ayat 34-35 dan hadist Nabi riwayat Imam Muslim. Para ulama fiqh telah bersepakat bahwa emas dan perak wajib dikeluarkan zakatnya apabila telah mencapai nishab dan telah berlalu satu tahun. Berdasarkan hadist Nabi yang diriwayatkan Abu Dawud, nishab zakat emas adalah dua puluh misqal atau dua puluh dinar, sedangkan nishab zakat perak adalah dua ratus dirham. Dua puluh misqal atau dua puluh dinar sama dengan delapan puluh lima gram emas. Dua ratus dirham sama dengan lima ratus sembilan puluh lima gram perak.

3. Perdagangan. Kewajiban zakat pada perdagangan yang telah memenuhi persyaratan tertentu dilandaskan pada Al-Qur'an Surat AlBaqarah ayat 267 dan hadist nabi yang diriwayatkan Abu Dawud. Hampir seluruh Ulama bersepakat bahwa perdagangan itu harus dikeluarkan zakatnya, apabila memenuhi persyaratan kewajiban zakat. Ada tiga persyaratan utama kewajiban zakat pada perdagangan, yaitu: Pertama,niat berdagang. Kedua, mencapai nishab. Ketiga, telah berlalu satu tahun.

4. Hasil Pertanian. Tanaman, tumbuhan, buahbuahan, dan hasil pertanian lainnya yang telah memenuhi persyaratan telah wajib zakat, harus dikeluarkan zakatnya. Hal ini sebagaimana dinyatakan dalam Al-Qur'an surat al-An'aam ayat 141 dan hadist Nabi yang diriwayatkan Imam Bukhari. Hadist Nabi telah membedakan besarnya zakat pertanian dari tanaman yang mempergunakan biaya yang besar dalam pengairannya, seperti sisitm irigasi, yaitu sebesar lima persen. Sedangkan yang tidak menggunkannya, zakatnya lebih besar, yaitu sepuluh persen.
5. Barang Tambang (ma'din) dan Barang Temuan (rikaz). Yang menjadi dasar diwajibkannya zakat pada temuan dan barang tambang yaitu sebuah hadist Nabi yang diriwayatkan oleh Sunan Ibnu Majah dari Abu Hurairah. Barang tambang wajib dikeluarkan zakatnya yang nishab nya sama dengan nishab emas dan perak, yaitu 20 misqal emas atau 200 dirham perak dengan kadar zakat sebesar 2,5 persen. Adapun untuk barang temuan zakat yang wajib dikeluarkan sebesar 20 persen yang harus disimpan di baitul mal untuk kepentingan dan kemaslahatan masyarakat.

\section{Sejarah Pengaturan Zakat}

Dari kajian sejarah, perintah kewajiban zakat sebenarnya tidak hanya diperlakukan pada masa Nabi Muhammad saja, akan tetapi sebelumnya pun sudah dikenakan kewajiban zakat. Dalam alQur'an banyak ditemukan ayat bahwa telah memerintahkan zakat kepada Nabi Ibrahim, Ishaq, dan Ya'qub. ${ }^{9}$ Islam datang dengan sebuah cita-cita ingin menghilangkan kesenjangan sosial antar orang-orang kaya dan orang miskin. Perlu diketahui bahwa pada awal kemunculan Islam, kota Mekkah menjadi pusat perdagangan yang sangat penting. Kondisi ini menyebabkan pola kehidupan masyarakat sangat materialisindividualistik. Berpijak dari fakta sejarah, dapat dikatakan bahwa kehadiran Islam bukan hanya mementingkan urusan peribadahan kepada Allah saja (bablumminallah), tetapi juga hubungan kepada manusia (bablumminannass). ${ }^{10}$

Pada pariode Makiyah, konsep shadaqah dan infak lebih popular dari pada konsep zakat. ibadah maliyah (ibadah yang berkenaan dengan harta) pada pariode ini mempunyai dampak sosial sangat dahsyat dengan adanya peningkatan kualitas sumber daya manusia (SDM) baik pribadi maupun kelompok. Banyak anggota masyarakat yang sebelumnya lemah dan berstatus hamba sahaya berubah menjadi merdeka dan mandiri, tawakal, sabar, dan berani. ${ }^{11}$ Pada pariode Madinah, istilah ibadah maliyah lebih popular menggunakan istilah

\footnotetext{
9 Asrifin an Nakhrawie, 2011, Sucikan hati dan Bertambah Rizki bersama zakat, Jakarta, Delta Prima Press hlm. 65. 10 Ibid, hlm. 59.

11 Mursyidi, 2006, Akuntansi Zakat Kontemporer, Bandung, PT. Remaja Rosdakarya. hlm. 79.
} 
zakat. Sampai sekarang, konsep zakat merupakan ibadah maliyah wajib, sementara konsep infak dan shadaqah kurang mempunyai makna subtansinya, bahkan dipahami sebatas ibadah maliyah sampingan. ${ }^{12}$

Dalam sejarah perUndang-undangan Islam, zakat baru diwajibkan di Madinah, tetapi Qur'an juga banyak menjelaskan hal-hal zakat dalam suratsurat yang turun di Mekkah. Adapun zakat yang termaktub di dalam surat-surat yang turun di Mekkah tidaklah sama dengan zakat yang diwajibkan di Madinah, dimana nishab dan besarnya sudah ditentukan, orang-orang yang mengumpulkan dan membagikannya sudah diatur, dan negara bertanggung jawab mengelolakannya. Zakat yang diatur di Mekkah adalah zakat yang tidak ditentukan batas dan besarnya, tetapi diserahkan kepada rasa iman, kemurahan hati, dan perasaan tanggungjawab seseorang atas orang lain sesama orang-orang yang beriman. ${ }^{13}$

\section{Urgensi Zakat Di Kelola Lembaga Zakat}

Pelaksanaan zakat didasarkan pada firman Allah yang terdapat dalam surat at-Taubah ayat 60 dan ayat 103. Dalam surat at-Taubah ayat 60 dijelaskan bahwa salah satu golongan yang berhak menerima zakat adalah orang-orang yang bertugas mengurus urusan zakat. Sedangkan dalam atTaubah ayat 103 dijelaskan bahwa zakat itu diambil dari orang-orang yang berkewajiban untuk berzakat dan kemudian diberikan kepada yang berhak menerimanya yang mengambil dan menjemput harta tersebut adalah para petugas (amil). 14

Imam al-Qurthubi ketika menafsirkan surat atTaubah ayat 60 menyatakan bahwa amil itu adalah orang-orang yang ditugaskan atau diutus oleh Imam (Negara) untuk mengambil, menuliskan, menghitung dan mencatat zakat yang diambil dari para muzakki untuk kemudiah diberikan kepada mustahiq. Karena itu, Rasulullah pernah memperkerjakan pemuda dari asad, yang bernama

12 Ibid, hlm. 80

13 Yusuf Qardawi, 1996, Hukum Zakat, Bogor, Litera antar Nusa, hlm. 61.

14 Didin Hafidhuddin, 2007, Agar Harta Berkab dan Bertambah, Jakarta, Gema Insani Press, hlm. 168.
Ibnu Luthaibah utnuk mengurus urusan zakat Bani Sulaim. ${ }^{15}$

Rasulullah pernah pula mengutus Ali bin Abi Thalib ke Yaman untuk menjadi amil zakat. Muaz bin Jabal pernah juga diutus oleh Rasulullah disamping bertugas sebagai da'i (menjelaskan ajaran Islam secara umum), juga mempunyai tugas khusus menjadi amil zakat. Demikian pula yang dilakukan oleh kbulafaur-rasyidin sesudahnya, mereka selalu mempunyai petugas khusus yang mengatur masalah zakat, baik pengambilan maupun pendistribusiannya. ${ }^{16}$

Yusuf Qardhawi mengungkapkan kesuksesan pengelolaan zakat akan sangat tergantung kepada: ${ }^{17}$

a. Para amil zakat (Ami) yang benar dan bagus yaitu harus muslim, jujur, terampil dalam bekerja sama dan memiliki pengetahuan yang cukup.

b. Ijtihad tentang jenis-jenis harta yang berkembang.

c. Dominasi fanatisme mazhab dan semangat taklid yang berlaku terhadap para ulama yang mereka pilih pendapatnya untuk menetapkan hukum-hukum zakat.

d. Lemahnya semangat keberagamaan dan pemahaman Islam dalam diri pribadi umat apabila pengelolaan zakat ditangani oleh pemerintah.

e. Banyak Negara yang pemerintahnya menangani urusan zakat namun sasaran zakat justru tidak tercapai sebagaimana yang diharapkan.

Pengelolaan zakat oleh lembaga zakat apalagi yang mempunyai kekuatan hukum formil memiliki beberapa kelebihan, yaitu: 18

1) Untuk menjamin kepastian dan pembayar zakat

2) Untuk menjaga perasaan rendah diri para mustahiq zakat apalagi berhadapan langsung untuk menerima zakat dari para muzakki

3) Untuk mencapai efesien dan efektifitas, serta sasaran yang tepat dalam penggunaan harta

15 Ibid, hlm. 169.

16 Didin Hafidhuddin, 2008, Zakat, Infaq, sedekah, Jakarta, Gema Insani Press, hlm. 125.

17 Yusuf Qardhawi, 1996, Op. cit, 168.

18 Didin Hafidhuddin, 2007, Op. cit. hlm. 170. 
zakat menurut skala prioritas yang ada pada suatu tempat titik. Untuk memperlihatkan syiar Islam dalam semangat penyelenggaraan pemerintahan yang Islami.

Dalam Undang-Undang Nomor 23 Tahun 2011 Tentang Pengelolaan Zakat menempatkan pemerintah melalui Badan Amil Zakat Nasional (BAZNAS), baik itu tingkat pusat, provinsi, kabupaten/kota sebagai pengelola tunggal (ami) dan lembaga Amil Zakat (LAZ) lembaga yang didirikan oleh masyarakat atas izin waliyyul amri (Negara) yang mempunyai tugas membantu BAZNAS dalam pengumpulan, pendistribusian, dan pendayagunaan zakat, dan Lembaga Amil Zakat (LAZ) wajib melaporkan secara berkala kepada Badan Amil Zakat Nasional (BAZNAS) atas pelaksanaan pengumpulan, pendistribusian, dan pendayagunaan zakat.

Dalam pasal 7 Undang-undang Nomor 23 tahun 2011 tersebut pembentukan Badan Amil Zakat Nasional dinyatakan mempunyai tugas pokok yaitu mengumpulkan, mendistribusikan dan mendayagunakan zakat. Adapun keberadaan organisasi pengelolaan zakat di Indonesia diatur oleh Undang-undang Nomor 23 Tahun 2011 tentang Pengelolaan Zakat. Meskipun harus diakui bahwa dalam peraturan-peraturan tersebut masih banyak kekurangan yang mendasar, misalnya tidak dijatuhkannya sangsi bagi muzakki yang melalaikan zakat, tetapi Undang-undang tersebut mendorong upaya pembentukan lembaga zakat.yang amanah, kuat, dan dipercaya oleh masyarakat.

Menurut pasal 30 dan pasal 31 Undang-Undang Nomor 23 Tahun 2011 Tentang Pengelolaan Zakat menjelaskan, bahwa dalam menunaikan tugasnya, Badan Amil Zakat Nasional (BAZNAS), dibiayai oleh Anggaran Pendapatan Belanja Negara dan hak amil, dan untuk BAZNAS Provinsi dan BAZNAS Kabupaten/kota dibiayai olen Anggaran Pendapatan Belanja Daerah dan hak amil.

Menurut pasal 16 (1) Undang-Undang Nomor 23 Tahun 2011 Tentang Pengelolaan Zakat, bahwa Dalam melaksanakan tugas dan fungsinya, BAZNAS, BAZNAS provinsi, dan BAZNAS kabupaten/kota dapat membentuk UPZ pada instansi pemerintah, badan usaha milik negara, badan usaha milik daerah, perusahaan swasta, dan perwakilan Republik Indonesia di luar negeri serta dapat membentuk Unit Pengumpul Zakat (UPZ) pada tingkat kecamatan, kelurahan atau nama lainnya, dan tempat lainnya.

Adapun persyaratan seseorang yang dapat diangkat menjadi amil menurut pasal 11 UndangUndang Nomor 23 Tahun 2011 Tentang Pengelolaan Zakat, yaitu:

1. Warga negara Indonesia.

2. Beragama Islam.

3. Bertakwa kepada Allah SWT.

4. Berakhlak mulia.

5. Berusia minimal 40 (empat puluh) tahun.

6. Sehat jasmani dan rohani.

7. Tidak menjadi anggota partai politik.

8. Memiliki kompetensi di bidang pengelolaan zakat.

9. Tidak pernah dihukum karena melakukan tindak pidana kejahatan yang diancam dengan pidana penjara paling singkat 5 (lima) tahun.

Secara umum, kehadiran Undang-Undang Nomor 23 tahun 2011 Tentang pengelolaan zakat ini sangat berperan dalam perkembangan organisasi pengelola zakat atau lembaga zakat di Indonesia, karena Undang-undang ini memberikan kepastian hukum bagi operasional organisasi pengelola zakat (OPZ), serta Meningkatnya kesadaran masyarakat dalam menunaikan zakat melalui lembaga zakat atau organisasi pengelola zakat (OPZ)

\section{Pendayagunaan Zakat Secara Produktif}

Sistim pendayagunaan zakat untuk usaha produktif sangatlah menarik untuk dibahas mengingat baik hukum Islam dan hukum positif Tentang Pengelolaaan zakat memberikan peluang kepada para amil (pengelola zakat) agar dana zakat yang terkumpul dapat digunakan untuk usaha produktif agar dapat meningkatkan perekonomian rakyat di Indonesia. Pendayagunaan zakat adalah inti dari keseluruhan kegiatan pengumpulan dana zakat. Di dalam mengoptimalkan fungsi zakat sebagai amal ibadah sosial mengharuskan pendayagunaan zakat diarahkan pada model produktif dari pada model konsumtif seperti ketentuan yang tercantum dalam Undang-undang Nomor 23 Tahun 2011 tentang Pengelolaan Zakat.

Pada dasaranya zakat itu sendiri mengandung makna produktif, artinya zakat itu tidak hanya ditujukan untuk sekedar memenuhi kebutuhan konsumtif fakir-miskin dan mustahik lainnya, tapi 
lebih dari itu ditujukan untuk memberdayakan kaum fakir-miskin dalam dalam rangka keluar dari jeratan kemiskinan mereka. Itulah sebenarnya tujuan dari ditegakannya hukum zakat. karena ketika zakat hanya diperuntukan untuk memenuhi kebutuhan konsumtif yang sifatnya harian, maka zakat itu sendiri tidak memenuhi tujuan idealnya. ${ }^{19}$

Pendayagunaan zakat dengan cara yang produktif dipahami sebagai hukum yang mendistribusikan atau memberikan dana zakat kepada mustabik secara produktif. Dana zakat diberikan dan dipinjamkan untuk dijadikan modal usaha bagi orang fakir, miskin dan orang-orang yang lemah. Salah satu tujuan zakat adalah agar harta benda tidak menumpukkan pada satu golongan saja, dinikmati orang-orang kaya sedangkan orang-orang miskin pada larut dengan ketidak mampuannya dan hanya menonton saja. Dalam hal tersebut dapat dilakukan dengan melaksanakan zakat produktif. Karena bila zakat selalu atau semuanya diberikan dengan cara konsumtif, bukannya mengikut sertakan mereka tetapi malah membuat mereka malas dan selalu berharap belas kasih dari si kaya, membiasakan mereka dengan tangan bawah, meminta dan menunggu belas kasih.

Pendayagunaan harta produktif untuk konteks pada zaman sekarang sangatlah diperlukan, karena dengan pendayagunaan harta zakat secara produktif tersebut yang diterima oleh mustahiq tidak habis begitu saja, akan tetapi bisa dikembangkan sesuai dengan kehendak dan tujuan zakat itu sendiri, yaitu menghilangkan kemiskinan dan mensejahterakan bagi kaum miskin dengan harapan secara bertahap mereka tidak selamanya menjadi mustahiq melainkan akan mejadi murakeki.20

Dengan begitu harta zakat semakin berkembang sehingga akan menjadi jumlah yang cukup banyak. Pengembangan tersebut tetap diarahkan utnuk membantu menyantuni mustahiq menuju kemandirian mereka. Dan tentunya pengembangan harta zakat tersebut disesuaikan dengan perkembangan zaman dan berdasarkan

19 M. Umar, 2008,Pendayagunaan Zakat Untuk Usaha Produktif, Jakarta, GP Press, hlm. 50.

20 Mu'inan Rifi, 2011, Potensi Zakat (dari konsumtif-kariatif ke produktif-berdayaguna)Perspektif Hukum Islam, Yogyakarta, Citra Pustaka, hlm. 142. kehendak kemaslahatan dan tidak terlepas dari tuntutan syari'at Islam sehingga makna dari konsepsi zakat itu bisa tersalurkan dalam penentuan kebijaksanaan pendayagunaan zakat serta tidak mengaburkan arti dari konsepsi zakat itu sendiri. ${ }^{21}$

Mengenai bolehnya zakat produktif ini, sebagaimana yang dimaksud Yusuf Qardhawi, bahwa Menunaikan zakat termasuk amal ibadah sosial dalam rangka membantu orang-orang miskin dan golongan ekonomi lemah untuk menjunjung ekonomi mereka sehingga mampu berdiri sendiri dimasa mendatang dan tabah dalam mempertahankan kewajiban-kewajibannya kepada Allah. ${ }^{22}$

Adapun cara pembagian zakat produktif, dengan menciptakan pekerjaan berarti amil dalam hal ini pemerintah dapat menciptaan lapangan pekerjaan dengan dana zakat,seperti perusahaan, modal usaha atau beasiswa, agar mereka memiliki suatu usaha yang tetap dan ketrampilan serta ilmu untuk menopang hidup kearah yang lebih baik dan layak. ${ }^{23}$

Pola pendayagunaan yang bersifat produktif dapat dipertimbangkan melalui beberapa alternatif antara lain: ${ }^{24}$

a. Pada saat tertentu, harta zakat yang diberikan kepada mustahiq (khususnya fakir miskin) dibagi dua, yaitu untuk pemenuhan yang besifat konsumtif dan satu bagian lagi diberikan dalam bentuk modal kerja sesuai dengan keahliannya, untuk diarahkan kepada pemenuhan jangka panjang (bersifat produktif).

b. Pada saat yang lain harta zakat itu didayagunakan dalam bidang pendidikan melalui beasiswa anak yatim piatu dan fakir miskin, serta anak jalanan dan anak asuh.

c. Dengan cara menginvestasikan harta zakat kepada suatu bentuk modal usaha yang dapat menyediakan lapangan pekerjaan dan latihan kewirausahawan bagi mustahiq, seperti mendirikan pabrik kerajinan, perusahaan pertanian

21 Ibid.

22 Yusuf Qadhawi, 1966, Musykilah al-Faqr wa Kaifa Aalajaha al Islam, Beirut, Muassasah Risalah, hlm.127.

23 Asnainu, 2008, Zakat Produktif Dalam Persfektif Hukum Islam, Bengkulu, Pustaka Pelajar, hlm. 93.

24 Mu'inan Rifi, Op. cit, hlm 7. 
dan lain-lain yang dapat menyerap tenaga kerja dengan maksud agar tersedianya lapangan kerja bagi mustabiq zakat dan bukan lagi menjadi pengangguran dan pemintaminta.

Dalam kaitan dengan penyaluran zakat yang bersifat produktif, Yusuf Qardhawi, Zakat menyatakan bahwa pemerintah Islam diperbolehkan membangun pabrik-pabrik atau perusahaanperusahaan dari uang zakat untuk kemudian kepemilikan dan keuntungannya bagi kepentingan fakir miskin. Dengan demikian maka zakat bukan hanya memenuhi kebutuhan konsumtif mereka buat sehari atau dua hari, namun juga seluruhan kebutuhan finansial mereka kelak. ${ }^{25}$

Pendayagunaan zakat secara produktif dapat memberikan dorongan untuk membuka usaha bagi para mustahiq, walaupun adakalanya zakat yang diberikan yang diberikan hanya berbentuk pinjaman lunak tanpa guna dan agunan yang harus dikembalikan dalam jenjang waktu yang tidak mengikat. Karena maksud pengembalian hanya untuk mendorong penerima pinjaman dapat berupaya sungguh-sungguh dalam mengembangkan usahanya. ${ }^{26}$

Pada sebuah kasus tidak jarang pengelolaan zakat dalam bentuk pemberian modal dapat dilegalkan dalam bentuk bank, seperti sebuah bank yang didirikan oleh Muhammad Yunus di Banglades, yang tujuannya adalah memberikan bantuan modal bagi para pengemis Banglades agar mereka terdorong mendapatkan pekerjaan dan usaha. Pinjaman sendiri tidak deperbolehkan untuk dikembalikan melalui pengemis, namun harus dikembalikan melalui usaha dan kerja keras. ${ }^{27}$

Pendayagunaan zakat produktif sangat efektif dalam memberantas kemiskinan. Dan jika dilihat dari tujuan utama adanya perintah zakat itu sendiri, maka bisa dipastikan bahwa zakat secara produktif inilah yang dikehendaki Islam, karena lebih sesuai dengan ruh perintah zakat yang ingin mengentaskan seseorang dari keterpurukan ekonomi. Lagi pula, jika diteliti secara seksama akan ditemukan indikasi bahwa maksud pemberian zakat kepada delapan golongan untuk menjamin

\footnotetext{
M. Umar, Op. cit, hlm . 54.

Ibid.

Ibid.
}

kesejahteraan golongan-golongan yang lemah dalam masyarakat. ${ }^{28}$

Dalam pasal 27 Undang-undang Nomor 23 Tahun 2011 Tentang Pengelolaan Zakat menyatakan bahwa:

1) Zakat dapat didayagunakan untuk usaha produktif dalam rangka penanganan fakir miskin dan peningkatan kualitas umat.

2) Pendayagunaan zakat untuk usaha produktif sebagaimana dimaksud pada ayat (1) dilakukan apabila kebutuhan dasar mustahik telah terpenuhi.

3) Ketentuan lebih lanjut mengenai pendayagunaan zakat untuk usaha produktif sebagaimana dimaksud pada ayat (1) diatur dengan peraturan Menteri

Kalau dillihat dari penjelasan Undang-undang Nomor 23 Tahun 2011 Tentang Pengelolaan zakat ini, dapat ditarik kesimpulan bahwa secara yuridis membenarkan adanya pendayagunaan zakat secara produktif dan mendapatkan perhatian yang sangat besar untuk memaksimalkan pendayagunaan zakat secara produktif dalam meningkatkan perekonomian rakyat Indonesia.

\section{Peran Zakat Dalam Peningkatan Perekonomian Ummat}

Sebagaimana diketahui, bahwa sistim zakat ternyata mempunyai peranan aktif dalam perekonomian. Karena zakat merupakan pungutan yang mendorong kehidupan ekonomi hingga terciptanya pengaruh-pengeruh tertentu. ${ }^{29}$ Integrasi zakat dalam menentukan kebijakan ekonomi nasional sangatlah diperlukan. Apalagi secara teoritis, aplikasi zakat dalam kehidupan perekonomian akan memberikan sejumlah implikasi penting. Berdasarkan Qur'an Surah alBaqaroh ayat 275-281, ada tiga sektor penting dalam perekonomian menurut al-Qur'an, yaitu: ${ }^{30}$

Sektor riil (al-bal), yaitu bisnis dan
perdagangan.

28 Asrifin An Nakhrawie, Op. cit, hlm. 172

29 Sauqi Ismail Sahhatih, 2007, Penerapan Zakat Dalam Bisnis Modern, Bandung, Pustaka Setia, hlm. 83.

30 Indonesia Zakat \& Development Report, 2011, Kajian Empiris Peran Zakat Dalam Pengentasan kemiskinan, Ciputat, Indonesia Magnificence of Zakat (IMZ), hlm.9. 
b. Sektor keuangan atau moneter, yang diindikasikan oleh larangan riba.

c. Zakat, infak dan sedekah (ZIS)

Sebagai pilar ketiga dalam perekonomian, zakat memiliki fungsi yang sangat penting dalam pertumbuhan ekonomi (Qur'an surah Ar-Rum ayat 39). Ini tercermin pada dua konsep utama, yaitu pertumbuhan ekonomi berkeadilan dan mekanisme sharing dalam perekonomian (Qur'an surat Adz-Dzariyat ayat 39). Tujuan utamanya adalah untuk meningkatkan kesejahteraan kaum dhuafa. Pada jangka pendek, kebutuhan mustabiq dapat terpenuhi, sementara pada jangka panjang, daya tahan ekonomi mereka akan meningkat. ${ }^{31}$

Zakat adalah salah satu institusi terpenting dalam kerangka sosial-ekonomi Islam. Dalam AlQur'an, perintah shalat juga seringkali diikuti dengan perintah zakat. Hal ini secara jelas menyiratkan betapa pentingnya zakat yang berdemensi sosial-herizontal (babluminannas) yang disetarakan dengan shalat yang berdimensi trasendental-vertikal (habluminallab). ${ }^{32}$

Zakat merupakan ketentuan yang diperintahkan langsung oleh Allah memiliki hikmah yang begitu penting. Zakat didalam Islam, memiliki peran penting dalam hal pemberdayaan ekonomi umat, dimana zakat berperan sebagai sistim mekanisme distribusi pendapatan dan kekayaan antar diantara umat manusia. Zakat yang dikelola dengan baik, dapat digunakan untuk menciptakan pertumbuhan ekonomi sekaligus pemerataan pendapatan. ${ }^{33}$

Dalam sistim ekonomi Islam, zakat dapat berperan sebagai distribusi kapital bagi masyarakat. Dengan pendistribusian zakat dari muzakki kepada mustabiq, berarti terjadi proses distribusi untuk pemerataan sumber daya ekonomi. Sumber daya dari muzakei kepada mustabiq akan membantu kehidupan rakyat sehingga mendorong pertumbuhan dan peningkatan ekonomi. ${ }^{34}$

Dampak zakat atas kemaslahatan masyarakat dan perekonomian Islam sangatlah jelas. Karena dalam zakat itu sendiri terdapat unsur pemberian bantuan kepada orang-orang fakir, disamping mewujudkan kepentingan yang bersifat umum. Ini

31 Ibid, hlm. 10.

32 Indonesia Zakat \& Development Report, 2010, Op. cit, hlm. 97.

33 Ibid.

34 Noor Aflah, Op. cit, hlm. 14. dapat dilihat secara jelas dari pos-pos pendistribusian zakat. Dengan zakat berarti kekayaan itu didistribusikan dari kalangan orangorang kaya kepada orang-orang fakir. Dengan cara seperti ini, maka terdapat unsur pemerataan kekayaan, sehingga kekayaan tidak menggelembung di pihak tertentu, sementara masih adanya kemelaratan di pihak lain. ${ }^{35}$

Sebagai sebuah sistim fiskal komprehensif yang lahir pada abad ke tujuh Masehi, zakat adalah sistim fiskal pertama didunia yang memiliki kelengkapan aturan yang luar biasa mulai dari subjek pembayar zakat, objek harta zakat beserta tarifnya masing-masing, batas kepemilikan harta minimal tidak terkena zakat (nishab), masa kepemilikan harta (haul), hingga alokasi distribusi dana zakat. Pada saat yang sama, zakat juga memiliki berbagai karakteristik dan implikasi ekonomi yang penting dan signifikan, yang membuatnya diinginkan secara sosial. 36

Dalam konteks sosial ekonomi, institusi zakat memiliki berbagai implikasi ekonomi penting baik ditingkat mikro maupun makro. Ditingkat mikro, zakat memiliki implikasi ekonomi terhadap perilaku konsumsi dan tabungan individu serta perilaku produksi dan investasi perusahaan tanpa berpengaruh negatif pada insentif bekerja. Sedangkan ditingkat makro, zakat memiliki implikasi ekonomi terhadap efisiensi alokatif, penciptaan lapangan pekerjaan, pertumbuhan ekonomi, stabilitas makro ekonomi, distribusi pendapatan, pengentasan kemiskinan dan jarring pengaman sosial. ${ }^{37}$

Dengan adanya zakat dapat meningkatkan pendapatan fakir dan miskin yang pada akhirnya konsumsi yang dilakukan juga akan mengalami peningkatan. Secara teori, dengan adanya peningkatan konsumsi maka sektor produksi dan investasi akan mengalami peningkatan. Dengan demikian, permintaan terhadap tenaga kerja ikut meningkat sehingga pendapatan dan kekayaan masyarakat juga akan mengalami peningkatan. Fenomena tersebut mengindikasikan adanya

\footnotetext{
35 Muhammad bin Shalih Al-Utsaimin, 2011, Fiqh Zakat Kontemporer, Solo, Al-Qowam, hlm. 13.

36 Indonesia Zakat \& Development Report, 2009, Op. cit, hlm. 33 .

37 Ibid.
} 
pertumbuhan kehidupan ekonomi dan sosial masyarakat. ${ }^{38}$

Adapun fungsi zakat dalam meningkatkan ekonomi, yaitu: ${ }^{39}$

1) Sebagaimana kita ketahui bahwa sistim perpajakan erat hubungannya dengan sistim perekonomian. Demikian pula pungutan zakat, ternyata mempunyai peranan aktif dalam perekonomian. Karena ia merupakan pungutan yang mendorong kehidupan ekonomi hingga tercipta padanya pengaruhpengaruh tertentu.

2) Zakat berikut kekayaan yang dipenggalnya dan pembelanjaan hasil pungutan zakat, khususnya pembelanjaan pada bidang-bidang sosial tertentu dan diketahui adalah aktif dalam mendistribusikan kembali pendapatan dan kekayaan kepada masyarakat karena zakat itu dipungut dari orang-orang kaya, diberikan kepada orang-orang fakir.

3) Pembagian zakat juga memainkan peranan ekonomi yang penting dalam mendorong peredaran uang dan memperluas arus uang. Karena dengan adanya zakat, semakin kuatlah daya beli. Dengan demikian, terjadilah pembelanjaan konsumtif untuk memperoleh barang ataupun jasa. Zakat juga aktif dalam merealisasikan keseimbangan yang stabil antara arus barang dan arus uang. Seperti diketahui antara arus barang dan arus uang berjalan dari arah yang berlawanan yang satu menyempurnakan yang lain. Akan tetapi, dengan adanya pembagian zakat secara luas, maka dapat meningkatkan pembelanjaan umum untuk dikonsumsikan pada barang dan jasa. Karena orang-orang fakir dan miskin yang tidak berpenghasilan sama sekali atau yang paspasan saja, akan mendapat bantuan pendapatan berupa uang yang kemudian mereka gunakan untuk memenuhi konsumsi keluarganya dan membeli barang dan jasa yang mereka butuhkan.

Secara singkat dijelaskan bahwa pengaruh ekonomis dari zakat tampak dalam hal-hal sebagai berikut:40

38 Said Sa'ad Marthon, 2007, Ekonomi Islam, Jakarta, Zikrul hakim, hlm. 128.

39 Ismail Nawawi,Op. cit, hlm. 100. a) Pengaruh zakat terhadap produksi. Dengan adanya zakat, fakir miskin dapat memenuhi kebutuhan dasarnya. Seluruh pemasukan yang mereka dapatkan dari zakat akan dikonsumsikan untuk memenuhi kebutuhan sekunder mereka. Dengan demikian, permintaan yang ada dalam pasar akan mengalami peningkatan, dan seorang produsen harus meningkatkan produksi yang dilakukan untuk memenuhi kebutuhan yang ada.

b) Dengan diwajibkannya Zakat, hal tersebut akan mendorong untuk melakukan investasi. Dengan alasan, jika tidak melakukan investasi, maka dia akan mengalami kerugian finansial.

c) Zakat berpengaruh untuk pertumbuhan ekonomi. Zakat menyebabkan meningkatnya pendapatan fakir miskin yang pada akhirnya konsumsi yang dilakukan juga akan mengalami peingkatan. Secara teori, dengan adanya peningkatan konsumsi maka sektor produksi dan investasi akan mengalami peningkatan. Dengan demikian permintaan terhadap tenaga kerja ikut meningkat sehingga pendapatan dan kekayaan masyarakat juga akan mengalami peningkatan.

\section{Konsep Zakat Sebagai Sarana Dalam Menghapus Kemiskinan}

Seperti kita ketahui bersama, kemiskinan terus menjadi masalah utama pembangunan hingga era modern saat ini. Kemiskinan tetap ada walau berada ditengah tingkat pertumbuhan yang menyakinkan. Salah satu insrumen terpenting dalam Islam untuk mengatasi masalah kemiskinan adalah zakat. zakat adalah instrument religius yang membantu individu dalam masyarakat untuk menolong penduduk fakir dan miskin yang tidak mampu menolong dirinya sendiri.

Institusi zakat adalah program pengentasan kemiskinan wajib (mandatory expenditure) dalam perekonomian Islam. Dampak zakat terhadap upaya pengentasan kemiskinan adalah sesuatu yang signifikan dan berjalan secara otomatis (built-in) di dalam sistim Islam.

40 Ibid, hlm. 126. 
Terdapat ada beberapa alasan untuk ini, yaitu: ${ }^{41}$

a. Penggunaan atau alokasi dana zakat sudah ditentukan secara pasti di dalam syari'at Islam (Q.S. At-Taubah: 60) dimana zakat hanya diperuntukan bagi 8 golongan (ashnaf) saja, yaitu: fiqara (fakir), masakin (miskin), amilin alaiha (pihak pengelola zakat, muallafat ul qulub (orang yang dijinakan hatinya), fir riqab (membebaskan budak), gharimin (orang yang berutang), fi sabilillah (berjuang dijalan Allah), dan ibn us sabil (orang yang sedang dalam perjalanan). Jumhur ulama sepakat bahwa selain bahwa selain delapan golongan ini, tidak halal menerima zakat. Lebih jauh lagi, alQur'an menyebutkan fakir dan miskin, sebagai kelompok pertama dan kedua dalam daftar penerima zakat. Mereka inilah yang mendapat prioritas dan pengutamaan oleh alQur'an. Ini menunjukan bahwa menatasi masalah kemiskinan merupakan tujuan utama dari zakat.

b. Zakat dikenakan pada basis yang luas dan meliputi berbagai aktifitas perekonomian. Zakat dipungut dari produk pertanian, hewan peliharaan, simpanan emas dan perak. Aktifitas perniagaan komersial, dan barangbarang tambang yang diambil dari perut bumi. Fiqh kontemporer bahkan memandang bahwa zakat juga diambil dari seluruh pendapatan yang dihasilkan dari aset fisik dan finansial serta keahlian pekerja. Dengan demikian, potensi zakat adalah sangat besar. Hal ini menjadi modal besar yang penting bagi pembiayaan program-program pengentasan kemiskinan.

c. Zakat adalah pajak spiritual yang wajib dibayar oleh setiap muslim. Dalam kondisi apapun. Karena itu, penerimaan zakat cenderung stabil. Hal ini akan menjamin keberlanjutan program pengentasan kemiskinan yang umumnya membutuhkan jangka waktu yang relatif panjang,

Dengan berbagai karakteristik yang disandangnya tersebut, keberadaan zakat dalam

41 Indonesia Zakat Development Report, 2009, Zakat Dan Pembangunan: Era Baru Menuju Kesejabteraan Ummat, Ciputat, Indonesia Magnificence of Zakat (IMZ), hlm. 43. kerangka sosial-ekonomi Islam menjadi basis yang kuat bagi program pengentasan kemiskinan secara berkelanjutan. Sebagai sebuah instrumen fiskal yang berpihak kepada kelompok miskin dan mejadi program wajib pengentasan kemiskinan bagi setiap rezim pemerintahan, zakat sangan superior dibandingkan instrumen fiskal konvensional. 42

Peran zakat dalam mengentaskan kemiskinan adalah peran yang tidak bisa dipungkiri keberadaannya, baik dalam kehidupan muslim atau kehidupan lainnya. Masyarakat umum hanya mengetahui bahwasanya tujuan dari zakat adalah mengentaskan kemiskinan dan juga membantu para fakir miskin, tanpa mengetahui gambarannya secara gamblang. 43

Islam memandang kemiskinan merupakan satu hal yang mampu membahayakan aqidah, akhlak, kelogisan berpikir, keluarga dan juga masyarakat. Islam juga menganggapnya sebagai musibah dan bencana yang harus segera ditanggulangi. ${ }^{44}$ Terlebih, jika kemiskinan tersebut makin banyak maka ia akan menjadi kemiskinan yang mampu membuatnya lupa akan Allah dan juga kemanusiaannya. Adanya keterkaitan yang kuat antara kefakiran dan kekafiran, karena kefakiran merupakan satu langkah menuju kekafiran. Hal ini karena orang yang fakir miskin cenderung memiliki potensi dalam dirinya untuk menebarkan benih keraguan terhadap kebijaksanaan ilahi mengenai pembagian rezeki. 45

Hadist Nabi Muhammad SAW:46

Artinya: Sesungguhnya Allah SWT telah mewajibkan atas orang kaya muslim suatu kewajiban zakat yang dapat menanggulangi kemiskinan. Tidak mungkin terjadi seorang fakir menderita kelaparan atau kekurangan sandang kecuali dikarenakan kebakbilan (pelit) orang kaya muslim. Ingatlah, Allah SWT akan melakukan perhitungan yang teliti serta meminta pertanggung jawaban mereka, lalu akan menyiksa mereka

\footnotetext{
42 Ibid.

43 Yusuf Qardhawi, 2005, Spektrum Zakat Dalam Membangun Ekonomi Kerakyatan, Jakarta, Zikrul Hakim, hlm. 29.

44 Ibid, hlm. 24.

45 Ibid, hlm. 26.

46 Didin Hafidhuddin, 1998, Panduan Praktis Tentang Zakat, Infak, Sedekah, Jakarta, Gema Insani, hlm. 16
} 
dengan siksaan yang pedih. (H.R. Imam alAshbahani)

Adapun hadist tersebut diatas memberikan dua isyarat, yaitu: ${ }^{47}$

1) Kemiskinan dan kefakiran yang diderita umat bukan semata-mata karena kemalasan mereka dalam bekerja, tetapi diakibatkan juga oleh ketimpangan dan tidak adilnya pola kehidupan, serta tidak ada tanggung jawab sosial para hartawan kepada kaum fakir dan miskin.

2) Jika zakat dikelola (pengambilan dan pendistribusiannya) dengan baik dan benar, insya Allah akan mampu menanggulangi atau paling tidak memperkecil kemiskinan dan kefakiran yang kini dihadapi sebagian umat.

Pemerataan kesejahteraan masyarakat dengan mekanisme zakat untuk menanggulangi kemiskinan secara berkelanjutan akan semakin terwujud karena pertimbangan sebagai berikut: ${ }^{48}$

a) Zakat adalah salah satu bentuk hak (tabungan) masyarakat miskin yang melekat atau dilekatkan pada harta si kaya dalam jumlah tertentu.

b) Zakat adalah hak fakir miskin yang melekat pada penghasilan masyarakat luas yang masuk ke dalam kolam harta orang kaya yang terjadi, baik karena proses eksploitasi tenaga kerja orang miskin dan tidak berdaya dalam proses produksi (teori nilai lebih) atau proses transaksi di pasar barang karena orang miskin lemah dalam posisi tawar mereka.

c) Hanya dengan mekanisme zakat hak fakir miskin tersebut secara jelas dan terarah dapat dinikmati masyarakat miskin.

d) Mekanisme zakat secara sengaja dipersiapkan oleh Allah SWT agar disalurkan untuk menaggulangi kemiskinan karena tuntunan iman dan pertimbangan kemaslahatan lain dalam masyarakat miskin.

Zakat memiliki peran penting dalam mengentaskan kemiskinan. Terlebih cukup banyak negara-negara yang hinga kini memanfaatkan zakat sebagai sarana pengentasan kemiskinan. Diantaranya Mesir dan Aljazair. Dikedua negara

47 Ibid, hlm. 17.

48 Sahri Muhammad, 2006, Mekanisme Zakat \& Permodalan Masyarakat Miskin, Malang, Bahtera Press, hlm. 45. tersebut, zakat dijaring dan dikelola secara optimal untuk berbagai program pengentasan kemiskinan. ${ }^{49}$ Adanya perintah zakat sebenarnya dimaksudkan agar tingkat kemiskinan tidak sampai terjadi, atau minimal tingkat kemiskinan bisa diminimalisir. Adanya perintah zakat juga memperjelas bahwa Islam mengajarkan pemerataan ekonomi, agar kekayaan tidak berkutat pada golongan elit saja hingga kesenjangan antara miskn dan kaya tidak Nampak mencolok. ${ }^{50}$

\section{Pengaruh Zakat Dalam Mengutrangi Pengangguran}

Pengangguran adalah sebuah paradok modernisasi. Dimana sebenarnya letak kelebihan masyarakat modern dibandingkan dengan masyarakat tradisional, jika pengangguran masih ada dan semakin luas berada disekitar manusia. Manusia ingin hidup sejahtera, namun pengangguran selalu mengancam manusia. Pesan Allah, hendaknya kita jangan meninggalkan turunan dan anak cucu generasi lemah. ${ }^{51}$

Kerangka sosial ekonomi perekonomian Islam secara jelas mendorong penciptaan lapangan kerja dapat dilakukan melalui dua jalur, yaitu: melalui penciptaan pekerjaan dengan upah tetap (fixed-wage job) maupun dengan menumbuhkan wirausahawan (extrepreneurial opportunities). Dan salah satu kerangka institusional terpenting dalam perekonomian Islam untuk penciptaan lapangan kerja ini adalah zakat. ${ }^{52}$

Pengangguran merupakan salah satu permasalahan yang berkaitan dengan kegiatan perekonomian, hubungan kemasyarakatan, dan juga permasalahan kemanusiaan. Apabila masalah pengangguran ini tidak dapat diselesaikan, maka akan muncul bahaya yang semakin hari semakin meluas dan berdampak buruk bagi kehidupan individu masyarakat, keluarga, dan juga masyarakat secara umum. Dampak buruk dari pengangguran terhadap individu masyarakat antara lain: ${ }^{3}$

a. Secara ekonomi, tidak mempunyai penghasilan atau pemasukan

\footnotetext{
49 Noor Aflah, Op. cit, hlm. 6.

50 Asrifin An Nakhrawie, Op cit, hlm 82.

51 Sahri Muhammad, Op. cit, hlm. 189.

52 Indonesia Zakat \& Development Report, 2009, Op. cit, hlm. 42.

53 Yusuf Qardhawi,2005, Op. cit, hlm. 4.
} 
b. Secara kesehatan akan mengurangi gerak tubuh dan langkah kaki

c. Secara kejiwaan, akan membuat seseorang hidup dalam kekosongan waktu

d. Secara kemasyarakatan, menimbulkan iri dan dengki atas keberhasilan orang lain

Ada yang berpendapat bahwa zakat dapat mendorong seseorang bergantung pada orang lain dan bermalas-malasan untuk bekerja sehingga akan menambah pengangguran. Pendapat seperti itu sanga keliru sekali, karena dengan adanya zakat, permintaan akan tenaga kerja semakin bertambah dan akan mengurangi pengangguran. Zakat akan meningkatkan produksi dan investasi dalam dunia usaha sehingga permintaan terhadap karyawan akan bertambah. ${ }^{54}$

Ada beberapa varian pengangguran yang memiliki konsekuensi hukum yang berbeda. Di antaranya adalah pengangguran yang sifatnya terpaksa, mau tidak mau keadaan memang menuntut untuk menganggur dan tidak ada pilihan lain. Ada beberapa sebab yang menjadi faktor munculnya pengangguran semacam ini. Diantaranya, seseorang yang memiliki keahlian berbisnis akan tetapi dia tidak memilik modal sama sekali untuk memulai bisnisnya, sehingga dia pun terpaksa menganggur. ${ }^{55}$ Atau keahliannya adalah bertani, akan tetapi sama sekali tidak memiliki instrumen dan segala perabotan untuk bertani, atau bahkan tidak memiliki ladang. Atau memiliki keahlian dalam profesi lain yang membutuhkan perangkat akan tetapi sama sekali tidak memiliki cukup uang untuk membelinya. Selain itu juga terdapat faktor lain, yaitu, tidak pernah menerima pendidikan tentang berprofesi pada masa kecilnya. Untuk yang terakhir ini tentunya yang sangat bertanggung jawab adalah kedua orang tuanya dan negara pada umumnya. ${ }^{56}$

Zakat memiliki peran signifikan untuk mengatasi pengangguran. Tujuan zakat bukan hanya mengurangi pengangguran yang fakir dan miskin dalam jangka pendek. Akan tetapi, tujuan esensialnya adalah mengentaskan pengangguran dalam jangka panjang, dengan cara mendayagunakan harta zakat untuk memodali mereka yang darinya mereka mampu

54 Said Sa'ad Marthon, Op. cit, hlm. 127.

55 Yusuf Qhardhawi,2005, Loc. cit.

56 Ibid. mengembangkanya sendiri sampai memiliki pemasukan yang mencukupi kebutuhan mereka selamanya.

\section{Penutup}

Kesimpulan

1. Zakat diwajibkan berdasarkan Al-Qur'an dan Hadist Nabi Muhammad. Dalil-dalil yang terdapat dalam Al-Qur'an banyak menggunakan bentuk amar (perintah) atau intruksi. Tidak hanya sebagai kewajiban kepada Allah yang bernilai ibadah, zakat juga mempunyai dimensi sosial. Dimana zakat mampu meningkatkan perekonomian ummat melalui fungsi distribusi kesejahteraannya.

2. secara khusus zakat dapat bermanfaat sebagai instrument untuk meningkatkan perekonomian ummat, dapat mengurangi penganggguran dan menghapuskan kemiskinan, karena zakat dapat berperan sebagai distribusi kapital bagi masyarakat. Dengan pendistribusian zakat dari muzakki kepada mustabiq, berarti terjadi proses distribusi untuk pemerataan sumber daya ekonomi. Sumber daya dari muzakki kepada mustahiq akan membantu kehidupan rakyat sehingga mendorong pertumbuhan dan peningkatan ekonomi.

3. untuk mendorong pemberdayaan zakat lebih maksimal dibutuhkan pelembagaan zakat khususnya melalui peraturan hukum positif yang dapat di terapkan untuk menjadi landasan pengelolaan zakat di Indonesia. Kehadiran Undang-Undang Nomor 23 tahun 2011 Tentang pengelolaan zakat menjadi instrument penting untuk mewujudkan cita-cita zakat yang mampu meningkatkan ekonomi ummat.

\section{Daftar Pustaka \\ Buku-Buku}

Al-Muhsin, Fakhruddin. 2011, Ensiklopedi Mini Zakat, Bogor, CV. Darul Ilmi

Ali, Muhammad Daud, 2006, Sistim Ekonomi Islam Zakat dan Wakaf, Jakarta, UI Press

As-Syaukani, 2000, Nailul Authar, Beirut, Dar Ibn Hazm

An Nakhrawie, Asrifin, 2011, Sucikan hati dan Bertambah Rizki bersama zakat, Jakarta, Delta Prima Press 
Syaikh, Yasin Ibrahim, ,2008, Kitab Zakat. Hukum, Tata Cara dan Sejarah, Bandung, Marja

Ambara, Iqbal M. 2009, Problematika Zakat Dan Pajak Di Indonesia, Bandung, Sketsa

Asnainu. 2008, zakat produktif dalam persfektif Hukum Islam, Bengkulu, Pustaka Pelajar

Aflah, Noor, 2009, Arsitektur Zakat Indonesia, Jakarta, UI Press

Departemen Agama, 2007. Lajnah Pentashib Mushaf Al-Qur;an, Solo, PT. Tiga Serangkai Pustaka Mandiri

Depag RI, 2002, Pedoman Zakat, Jakarta, Badan Proyek Peningkatan Zakat dan Wakaf

Djuanda, Gustian et.al, 2006, Pelaporan Zakat Pengurangan Pajak Penghasilan, Jakarta, PT, Raja Grafindo Persada

Fahruddin, 2008, Fiqib dan Manajemen Zakat Di Indonesia, Yogyakarta, UIN-Malang Press

Fauzan, Imam,2012, Tuntunan Zakat, Tangerang, Mediatama Publishing Group

Hafiduddin, Didin , 2007, Agar Harta Berkah dan Bertambah, Jakarta, Gema Insani Press ,2008, Zakat Dalam Perekonomian Modern, Jakarta, Gema Insani Press

Indonesia Zakat Development Report, 2009, Zakat Dan Pembangunan: Era Baru Zakat Menuju Kesejabteraan Ummat, Ciputat, Indonesia Magnificence of Zakat (IMZ) ,2010, Menggagas arsitektur Zakat di Indonesia, Ciputat, Indonesia Magnificence of Zakat (IMZ)

Khoir, M. Masykur.2010, Risalah Zakat, KediriIndonesia, Duta Karya Mandiri

Umar, M. 2008, Pendayagunaan Zakat Untuk Usaha Produktif, Jakarta, GP Press

Muhammad Baqir Ash-Shadar, Syahid. 2002, Keunggulan Ekonomi Islam, Jakarta, Pustaka Zahra

Mursyidi, 2006, Akuntansi Zakat Kontemporer, Bandung, PT Remaja Rosda Karya

Marton, Said Sa'ad, 2007, Ekonomi Islam. Di Tengah Krisis Ekonomi Global, Jakarta, Zikrul Hakim
Qardhawi, Yusuf,1966, Musykilah al-Faqr wakaifa Aalajaha al islam, Beirut, Muassasah Risalah 1996, Hukum Zakat, Bogor, Litera antar Nusa 2005, Spektrum Zakat Dalam Membangun Ekonomi Kerakyatan, Jakarta, Zikrul Hakim

Qadim Zallum, Abdul, 1983, Al-Amwal fi Dawlah al-Khilafah, Beirut, Darul al-Ilmi li al Malayin

Qadir, Abdurrahman, 1998, Zakat dalam Dimensi mahdhah dan Sosial, Jakarta, Raja Grafindo Persada

Rafi, Mu'inan, 2011, Potensi Zakat (dari konsumtifkariatif ke produktif-berdayaguna)Perspektif Hukum Islam, Yogyakarta, Citra Pustaka

Ridho, M. Taufiq, 2006, Pengelolaan Zakat di Negara-negara Islam, Jakarta, Forum Zakat

Shalih Al-Utsaimin, Muhammad, 2011, Fiqh Zakat Kontemporer, Solo, Al-Qowam

Sa'ad Marthon, Said, 2007, Ekonomi Islam, Jakarta, Zikrul hakim

Sahhatih, Syauqi Ismail, 2007, Penerapan Zakat Dalam Bisnis Modern, Bandung, Pustaka Setia

\section{Peraturan Perundang-undangan}

Qur'an

Hadits

Undang-Undang Dasar Republik Indonesia Tahun 1945

Undang-undang Nomor 23 Tahun 2011 Tentang Pengelolaan Zakat

Peraturan Pemerintah Republik Indonesia Nomor 60 Tahun 2010 Tentang Zakat atau Sumbangan Keagamaan Yang Sifatnya Wajib Yang Dapat Dikurangkan dari Penghasilan Bruto 